Nota Científica

\title{
Psyllaephagus trioziphagus (Hymenoptera: Encyrtidae), a Mastigimas anjosi parasitoid (Hemiptera: Calophyidae)
}

\author{
Valmir Antonio Costa ${ }^{1}$, Dalva Luiz de Queiroz ${ }^{2}$, Norivaldo dos Anjos Silva ${ }^{3}$ \\ ${ }^{1}$ Instituto Biológico, Rod. Heitor Penteado, km 3, CEP 13092-543, Campinas, SP, Brasil \\ ${ }^{2}$ Embrapa Florestas, Estrada da Ribeira, km 111, C. P. 319, CEP 83411-000, Colombo, PR, Brasil \\ ${ }^{3}$ Universidade Federal de Viçosa, Departamento de Biologia Animal, Casa dos Cupins, Av. P. H. Rolfs, s/n, Campus, CEP 36570-000, Viçosa, MG, Brasil
}

\begin{abstract}
"Autor correspondente:
dalva.queiroz@embrapa.br

Abstract - Psyllaephagus trioziphagus (Howard, 1885) was first observed feeding from Mastigimas anjosi Burckhardt et al., 2011 immatures, with just one parasitoid on each insect. This parasitoid was previously reported from Canada to Brazil. Although it is

Termos para indexação: not host-specific, it may be a useful agent to control M. anjosi in Brazil.

Meliaceae
\end{abstract}

Controle biológico

Index terms:

Forest entomology

Meliaceae

Biological control

Histórico do artigo:

Recebido em 05 fev 2015

Aprovado em 21 ago 2015

Publicado em 30 set 2015

doi: $10.4336 / 2015 . p f b .35 .83 .852$

\section{Psyllaephagus trioziphagus (Hymenoptera: Encyrtidae), parasitoide de Mastigimas anjosi (Hemiptera: Calophyidae)}

\begin{abstract}
Resumo - Psyllaephagus trioziphagus (Howard, 1885) foi observado pela primeira vez parasitando imaturos de Mastigimas anjosi Burckhardt et al., 2011, com apenas um parasitoide em cada imaturo. Este parasitoide foi previamente reportado desde o Canadá até o Brasil. Apesar de não ser hospedeiro específico, pode representar um agente útil no controle de M. anjosi no Brasil.
\end{abstract}

The Australian Red Cedar (Toona ciliata M. var. australis Roemer (F. Muell) Bahadur) is a Meliaceae commonly cultivated in Brazil to produce noble wood. Its wood is similar to the Brazilian cedar (Cedrela odorata L.) and to other species of Cedrela (Meliaceae). Despite being planted in several Brazilian states, few insects were reported as harmful to this essential tree. In 2010 and 2011, however, an intense attack of a psyllid species occurred in leaves and pointers of the Australian cedar trees grown commercially in the states of Minas Gerais (cities of Ouro Branco, Conselheiro Lafaiete and Florestal) and São Paulo (city of Bananal) (Burckhardt et al., 2011). The psyllid was identified as Mastigimas anjosi Burckhardt et al., 2011 (Figure 1).
The attack of this psyllid causes winding, deformation, chlorosis, spots and necrosis in leaflets (Figure 2). The leaflets attacked became yellow, withered and fell off. The attack of the psyllids cause the premature fall of the leaflets from the apex to the base of the leaf and the tree. The premature loss of leaves causes excessive lateral sprout, with subsequent loss of the apical dominance and super sprouting of the trees. Besides these damages, the immatures secrete a flocculent wax that accumulates on the leaflets, petioles and young branches. These waxes and sugary excretions expelled by psyllids favor the development of sooty mould, which covers leaves and buds, reducing photosynthesis. Attacked buds become dry and brittle, which facilitates the breakdown of trees by the wind (Queiroz et al., 2013). 


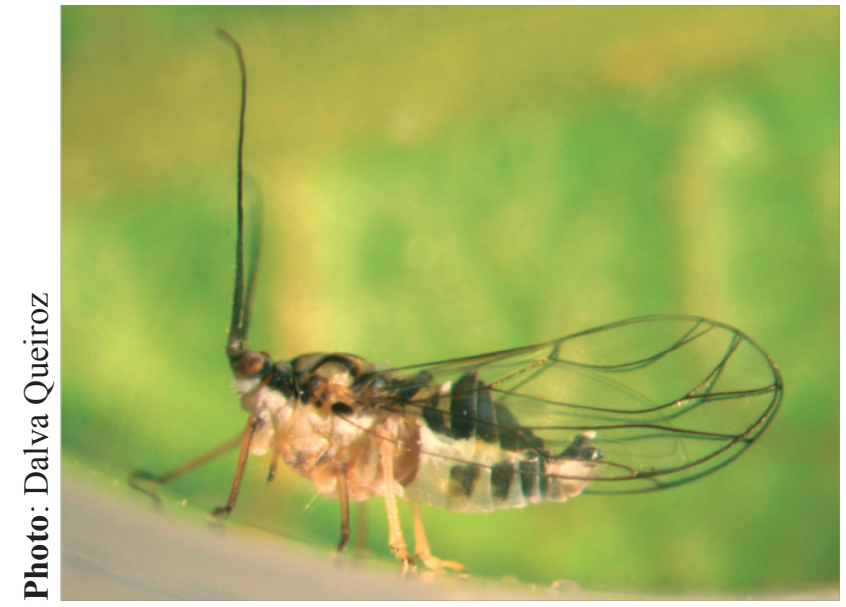

Figure 1. Adult Mastigimas anjosi (lateral view of a male).

In the outbreaks reported in the state of Minas Gerais (Queiroz et al., 2013), predators (Chrysopidae and Syrphidae) and parasitoids were also observed. The predators were observed along the $M$. anjosi colonies and, in some cases, Syrphidae larvae were observed attaccking the psyllid nymph.

Some fifth instar M. anjosi nymphs were collected in the field in the cities of Ouro Branco and Conselheiro Lafaiete, Minas Gerais, and placed in Petri dishes for parasitoids emergence.

The parasitoids were identified as Psyllaephagus trioziphagus (Howard, 1885) (Hymenoptera: Encyrtidae) (Figure 3), according to the concept of Noyes \& Hanson (1996).

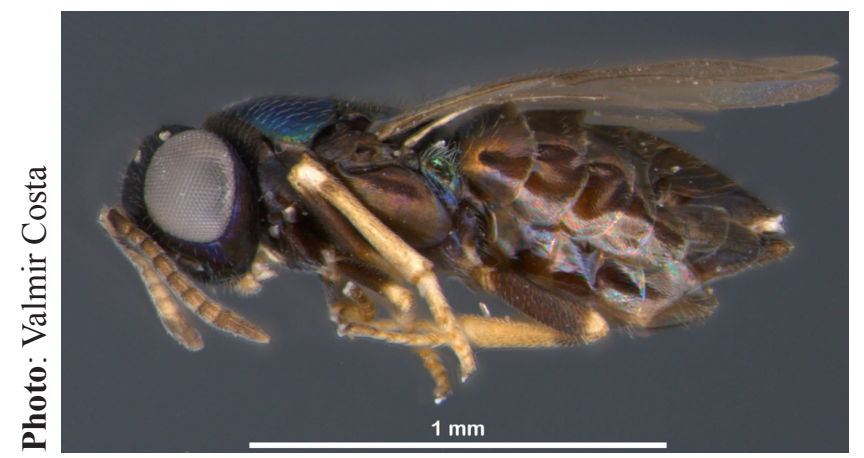

Figure 3. Female parasitoids Psyllaephagus trioziphagus.

P. trioziphagus obtained from $M$. anjosi, the face of females is metallic blue; Noyes \& Hanson (1996) and Myartseva et al. (2003) referred to it as metallic green, but according to the original description (Howard, 1885) it is Howard (1885) described it as metallic blue. Another observed variation is that the mesh of the cross-linked

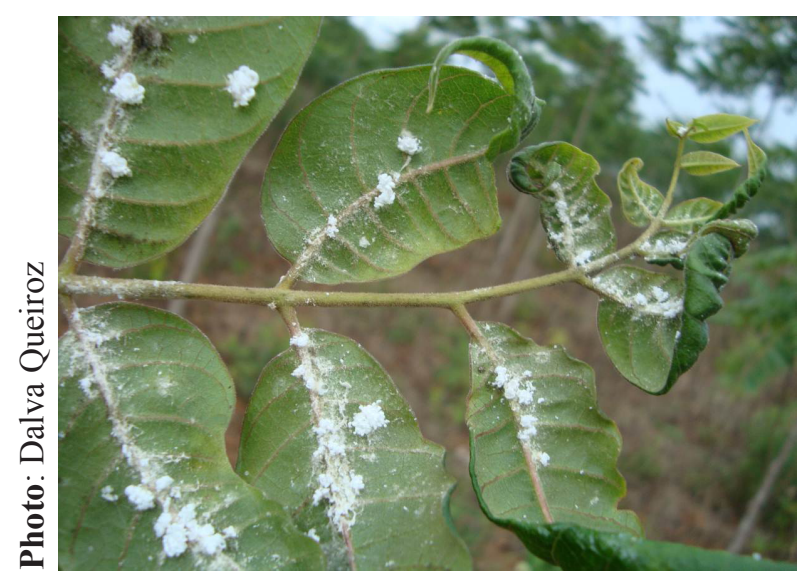

Figure 2. Mastigimas anjosi colonies with wax, on the bottom of the leaves of Toona ciliata in Conselheiro Lafaiete, Minas Gerais, Brazil, April 2014.

sculpture of the tegument scutellum is longitudinally reticulate in some areas of the scutum, different than the one mentioned by Myartseva et al. (2003). The copies Parasitoid specimens were deposited in the Collection of Entomophagous Insects "Oscar Monte", of the Biological Institute, established in Campinas, São Paulo, in the Biological Control Laboratory.

This parasitoid has occurrence records in Brazil (states of Mato Grosso do Sul, Rio Grande do Sul, Santa Catarina and São Paulo), Canada, Costa Rica, Cuba, the USA, Jamaica, Mexico, Panama and Peru. Noyes \& Hanson (1996) recorded this parasitoids for the following hosts: Calophyidae: "Mastigimas ernsti (Schw.)" [= Mastigimas ernstii (Schwarz, 1899)] in Cuba and Mastigimas sp. in Costa Rica; Triozidae: "Trioza diospyri (Asmead)" [= Baeoalitriozus diospyri (Ashmead, 1881)] in the USA, "Trioza sp. aff. Maritima" [= Trioza cf. maritima Tuthill, 1944] and Trioza sp. in Costa Rica, as well as "Triozoidea on guava" [= Triozoida limbata (Enderlein, 1918)] in Brazil. This parasitoid was observed in the states of São Paulo and Mato Grosso do Sul, in T. limbata immatures, in commercial orchards of guava trees (Melo, 2009; Sá \& Fernandes, 2015).

Psyllaephagus trioziphagus females (Figure 3) are around $1.3 \mathrm{~mm}$ long, and their predominant color is copper-brown, with dorsum of thorax metallic green and scutellum with a coppery or purple sheen. Scape and pedicel black with slight metallic sheen, flagellum brown. Femora dark brown and tibiae yellow; the wings are hyaline. Males are slightly smaller, about $1.0 \mathrm{~mm}$ long; they are similar to females in color and have 
antennae with shorter pedicel and scape and a flatter flagellum.

Although P. trioziphagus is not specific, this parasitoid represents a promising natural enemy for the integrated management of $M$. anjosi.

\section{Acknowledgments}

We would like to thank Dr. Daniel Burckhardt for his comments and suggestions to the manuscript.

\section{References}

BURCKHARDT, D.; QUEIROZ, D. L.; QUEIROZ, E. C.; ANDRADE, D.; ZANOL, K.; REZENDE, M. Q.; KOTRBA, M. The jumping plant-louse Mastigimas anjosi (Hemiptera, Psylloidea), a new pest of Toona ciliata (Meliaceae) in Brazil. Spixiana, Munchen, v. 34, n. 1, p. 113-124, 2011.

HOWARD, L. O. Descriptions of North American Chalcididae from the collections of the U.S. Department of Agriculture and of Dr C.V. Riley, with biological notes. Washington, DC, United States Department of Agriculture, 1885. p. 5-47. (U.S. Department of Agriculture. Bureau of Entomology. Bulletin, n. 5).
MELO, G. Dinâmica populacional e inimigos naturais de Triozoida limbata (Hemiptera: Triozidae) e diversidade de famílias de himenópteros parasitoides em pomar convencional e orgânico de goiaba na região de Campinas, SP. 2009. 51 f. Dissertação (Mestrado em Sanidade, Segurança Alimentar e Ambiental no Agronegócio) - Instituto Biológico, São Paulo.

MYARTSEVA, S. N.; MARTINEZ-RAMIREZ, J. A.; CORONADOBLANCO, J. M.; RUÍZ-CANCINO, E. A new species of Psyllaephagus Ashmead from Mexico (Hymenoptera: Encyrtidae). Zoosystematica Rossica, v. 11, n. 2, p. 357-360, 2003.

NOYES, J. S.; HANSON, P. Encyrtidae (Hymenoptera: Chalcidoidea) of Costa Rica: the genera and species associated with jumping plantlice (Homoptera: Psylloidea). Bulletin of the Natural History Museum: Entomology Series, London, v. 65, n. 2, p. 105-164, 1996.

QUEIROZ, D. L.; BURCKHARDT, D.; DOS ANJOS, N. Psilídeos no Brasil: 8 - Mastigimas anjosi (Hemiptera, Psylloidea), nova praga da Toona ciliata no Brasil. Colombo: Embrapa Florestas, 2013. (Embrapa Florestas. Comunicado técnico, 313). Disponível em: <http://www.infoteca.cnptia.embrapa.br/infoteca/bitstream/ doc/957826/1/CT313Dalvafinal.pdf>

SÁ, V. A.; FERNANDES, M. G. Himenópteros parasitoides associados a ninfas de Triozoida limbata na cultura da goiabeira, em Ivinhema, MS, Brasil. Ciência Rural, Santa Maria, RS, v. 451, p. 19-21, 2015. DOI: $10.1590 / 0103-8478$ cr20140382 
